Çukurova Üniversitesi Mühendislik Mimarlık Fakültesi Dergisi, 35(3), ss. 575-582, Eylül 2020

Çukurova University Journal of the Faculty of Engineering and Architecture, 35(3), pp. 575-582, September 2020

\title{
Aydınlatma Armatürleri için Soğutucu Modüllerinin Deneysel Değerlendirilmesi ve Yenilikçi Ürün Tasarımı
}

\author{
Ahmet FEYZIOOGLUU ${ }^{* 1}$ \\ ${ }^{1}$ Marmara Üniversitesi, Teknoloji Fakültesi, Makine Mühendisliği Bölümü, İstanbul
}

$\ddot{O} \mathbf{z}$

Geliş tarihi: 28.07.2020 Kabul tarihi: 23.10 .2020

Enerji çağımızın en önemli konularından biri haline gelmiştir. Enerjinin verimli kullanılması hem devletler hem de şirketler açısından hayati bir önem taşımaktadır. LED teknolojisi aydınlatma cihazları içerisinde en verimli cihazlar olarak görülmektedir. LED aydınlatıcıların soğutulması, cihazın ömrü ve performansı açısından son derece önemlidir. Bu çalışmada alüminyum bloklara göre daha hafif ve modüler yapıda, aydınlatma armatürleri için yüksek 1Sı atma kapasitesine sahip soğutucu modülüne sahip alternatif çözümler değerlendirilmiş ve yenilikçi bir tasarım geliştirilmiştir. Prototip olarak üretilen soğutucu modülü üzerinde sıcaklık testleri yapılmış ve sportif aydınlatması kullanımında uygunluğu incelenmiştir. Testler sonucunda 1sınma probleminin büyük ölçüde çözüldüğü gözlemlenmiştir. Modül içerisinde armatürleri soğutmak maksadıyla kullanılan herhangi bir fan gücüne ihtiyaç duyulmadığı için fazladan enerji harcanmayarak ısı transferinin sağlandığı görülmüştür.

Anahtar Kelimeler: Enerji, Aydınlatma, LED, Isı transferi, Soğutma

\section{Experimental Evaluation of Cooling Modules with High Heat Transfer Capacity for Illumination Armatures and Innovative Product Design}

\begin{abstract}
Energy has become one of the most important subjects of our age. Efficient use of energy is vital for both the governments and the companies. LED technology is known as the most efficient device among lighting devices. The cooling of the LED illuminators is crucial for their lifetime and performance. In this study, alternative solutions that have a lighter and modular structure than aluminum blocks, with a high heat transfer capacity for illumination armatures, have been evaluated and an innovative design has been developed. Temperature tests were performed on the cooling module produced as a prototype and its suitability for street lighting use was examined. As a result of the tests, it was observed that the warming problem was largely solved. Since no extra fan power is needed to cool the luminaire in the module, it is seen that heat transfer is provided without extra energy.
\end{abstract}

Keywords: Energy, Illumination, LED, Heat transfer, Cooling

"Sorumlu yazar (Corresponding author): Ahmet FEYZİĞLU, ahmet.feyzioglu@marmara.edu.tr 


\section{GIiRiş}

Yurtiçinde ve dünyada teknolojinin gelişimine paralel olarak ve aynı zamanda enerji tasarrufu sağlamak amacıyla artan LED'li aydınlatma cihaz kullanımı LED'li aydınlatma cihazlarının soğutulması gerekliliğini de beraberinde getirmektedir.

Gelişen bilim, teknoloji ve insanların enerji tasarruflu cihazlar kullanma bilinci doğrultusunda LED'ler, aydınlatma alanında oldukça geniş bir yer tutmaktadır [1]. LED'ler, kullanım alanlarında oldukça az yer kaplamaktadırlar ve buna rağmen oldukça yüksek verimlilik sağlamaktadırlar. Aydınlatmada özellikle de LED'lerde sürdürülebilirlik önem taşımaktadır [2]. Bilindiği üzere LED'ler 1şı yayarken 1 sı üretmektedir. LED'lerde üretilen 1sı hızlıca dışarı atılmadığı takdirde LED üzerinde bir 1sı birikmesi olur ve bu durumda LED'in çalışma koşulları, verimliliği ve çalışma ömrü, önemli derecede etkilenerek çok daha kısa zamanda problem oluşmasına neden olmaktadır [3]. Bu durum LED'li armatürler için de geçerlidir. Armatürde kullanılan LED'ler belirli bir 1sı üreterek çalışma ortamlarını, aynı sebepler dolayısıyla etkilemektedirler. LED'lerin ısınma problemini çözmek ve enerji verimliliğini arttırmak için yapılan çalışmaların çoğu geometrik şekilde değişiklikler aracılığılyla 1sı kanatçıklarının termal performansının geliştirilmesi üzerinedir [49]. Dikdörtgen, trapez, kesikli dikdörtgen, hizalı dairesel ve zikzaklı dairesel gibi farklı geometrilerdeki kanatçık yapılarının, soğutucunun termal performansı üzerinde farklı etkileri olduğu bilinmektedir [10]. Daha önceki metotlarda, alüminyum bloklara bağlanan LED'lerin oluşturduğu 1sı, alüminyum blok üzerinde şekillendirilmiş kanatçıklar vasıtasıyla dış ortama atılmaktadır. Burada LED'lerden çıkan 1s1, alüminyuma temas ederek iletim yoluyla daha ince olan kanatlara, daha sonra da kanatlardan diş ortama atılmaktadır. Bu yöntem sadece düşük güçteki LED’ler için uygun olmaktadır [11]. Yüksek güçteki LED'ler için bu metot yeterli olmamakta, oluşan 1sı alüminyum kontak noktasından kanatlara aktarılamamakta, kullanılan kanat sayısı ve büyüklüğü yetmemekte ve 1 sı dış ortama atılamamaktadır [12].

LED'ler belirli güç kapasitelerinde üretildiklerinden, kullanılacakları ortamlara göre güç kapasitesi bakımından farklılık göstermektedirler. IEC 61000-3-2 standardına göre aydınlatma sistemleri için kullanılan uygun güç 25 W'tır. Yüksek güç kapasitelerinde dış ortama daha fazla 1si enerjisi transfer edilmesi gerekmektedir. LED'lerin genel olarak çalışma sıcaklığı belirli sıcaklık değerleri arasında olduğundan dolayı bu limitlerin aşılmaması sağlanmalıdır. Geniş ve yüksek tavanlı mekânlarda daha iyi aydınlatma sağlanabilmesi amacıyla yüksek güç kapasitesine sahip LED'ler kullanıldığından dolayı bu LED'lerin daha iyi soğutulması gerekmektedir [13]. Daha iyi soğutma sağlayabilmek için ise soğutucu kanat yüzeylerinin artırılarak dış ortamla daha fazla temas etmesi sağlanmalıdır [14]. Bu durumda modül büyüklüğü sınırlanmıştır. Belirli büyüklük ve kanat yüzey alanından oluşan ısının tümü atılamadığında LED'in çalıştığı alanda bir 1sı birikimi olur ve bu ortamda sıcaklık artışı meydana gelir. Bu durum da LED'lerin çalışma verimini ve ömrünü etkileyerek, LED'in daha verimsiz çalışmasına ve daha kısa sürede problem yaşamasına neden olmaktadır. Diğer ürünlerden farklı olarak bu çalışmada yapılan tasarım; armatürde bulunan boru, kanatçık, malzeme seçimi ve üretim gibi tüm işlemleri kapsamaktadır. Gerekli soğutmanın yapılabilmesi için boru içinde kullanılan sıvının faz değişiminden faydalanılmıştır. Yapılan testler sonucunda diğer çalışmalarda kullanılan düşük akımlı (0-1A) LED'lerin aksine yüksek akımlarda çalışan LED'ler için de yeterli soğutmanın yapıldığ1 gözlemlenmiştir. Bir diğer karşılaşılan sorun ise, LED üzerinde oluşan ısıyı atarken büyük kütleler kullanıldığından dolayı LED'lerin takıldığı armatür ya da soğutucu- Printed Circuit Board (PCB-Baskılı Devre Kartı)-LED modülü ağır olmakta ve kullanıldığı yerde ağırlıktan kaynaklanan birtakım sorunlar teşkil etmektedir. $\mathrm{Bu}$ sorunlar; LED askı aparatlarının dayanım problemleri, asma tavanların ağırlık taşıma problemleri, insanların kullandığı alanlarda 
lambaların dayanıksızlığından dolayı meydana gelebilecek güvenlik problemleri gibi problemlerdir. $\mathrm{Bu}$ çalışmada, bu problemler göz önünde bulundurularak soğutucu modül kütlesini minimum düzeyde tutacak şekilde tasarım yapılmıştır. Ayrıca modülün montajı modülün ağırlık merkezinden yapıldığından yük dengeli olarak dağılmıştır. Bu durum malzeme dayanım, ağırlık taşıma ve güvenlik problemlerine doğrudan etkisi olmuştur.

\section{MATERYAL VE METOT}

\subsection{Soğutucu Modül Yapısı}

Geliştirilen soğutucu modülü (Şekil 1); boru kapak tıpası (1), alüminyum kanatçıklar (2), alüminyum kanatçık boğazları (3), bakır boru (4), bakır taban parçası (5) ve sinter parçası (6)'ndan oluşmaktadır.

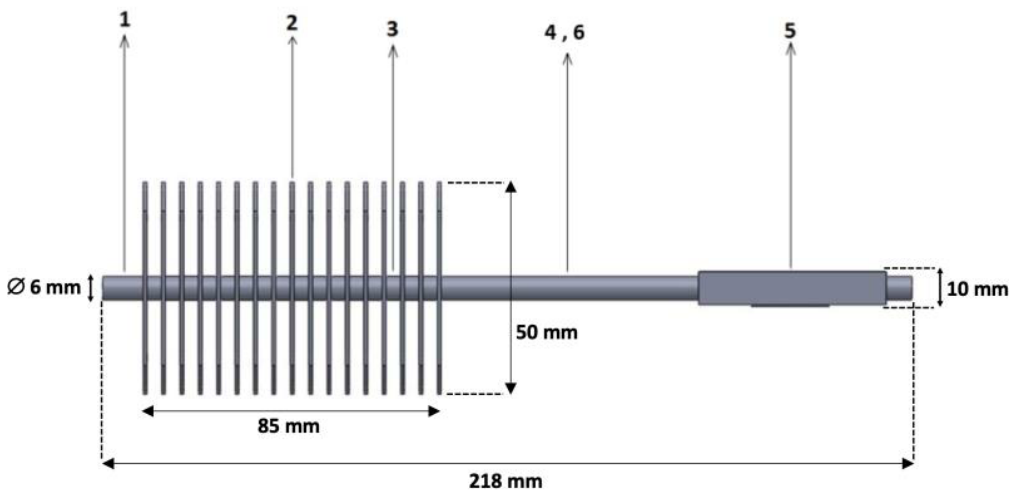

Şekil 1. Soğutma modülü parça analizi

Soğutucu modülü oluşturulurken boy optimizasyonu yapılmış, bakır borunun (4) çap1 6 $\mathrm{mm}$ ve boy uzunluğu $218 \mathrm{~mm}$ belirlenmiştir. Sportif aydınlatma ölçülendirilmesinde tanımlanan kompakt alan içerisinde hacim oluşturulmuştur. $65 \times 65 \times 230 \mathrm{~mm}^{3}$ hacim ölçüsü doğrultusunda Şekil 1 'de gösterildiği gibi uzunluklar belirlenmiştir. $\mathrm{Bu}$ oran korunarak soğutucu modülü ölçeklenebilir. Bakır malzemeden bakır boru (4) kesilerek iç çeperlerinde gözenekli ve boşluklu bir yap1 yaratmak amacıyla bakır tozları ile bakır boru (4) iç çeperi doldurulduktan sonra bir fırın içerisine yerleştirilmiştir. Fırın sıcaklığı belirli sıcaklık kademelerine belirli zaman aralıklarında çıkarılarak bakır tozlarının sıcaklıkla bakır boruya (4) yapışması sağlanarak sinter parçası (6) oluşturulmaktadır. Sinter parçası (6) ile bakır boru (4) tek bir parça olacak şekilde mühürlendikten sonra bakır borunun (4) sabitlenmesi için bir tarafından taban parçasına (5) kaynak yöntemi ile sabitlenerek bakır borunun (4) bir tarafi kapatılmıştır. Daha sonra 1sı transfer değerleri, kalınlık, boy, sertlik derecesi ve dizilecek kanatçık
(2) sayısı belirlenmiş ve optimize edilmiş alüminyum kanatçıklar (2) ortalarında bakır boru (4) çapından daha dar çapta bir delik bırakılarak presleme yöntemi ile bakır borunun (4) dış yüzeyine sıkı geçme yapacak şekilde yerleştirilmiştir. Aynı zamanda alüminyum kanatçıkların (2) ortasındaki deliğin bakır borunun (4) dışına sıvanmasıyla alüminyum kanatçık boğazları (3) oluşturulmuştur. Bunun sebebi 1sı transferinin bakır borudan (4) alüminyum kanatçıklara (2) daha hızlı ve daha büyük kapasitede transfer edilmesi sağlanmaktadır.

Bakır borunun (4) iç kısmında vakum ortamı yaratılarak akışkan bir sıvının buharlaşma ve yoğuşma yapması sağlanmıştır. Çevrimin gerçekleştirmesi için bakır borunun (4) diğer ucu da boru kapak tıpası (1) ile kapatılarak bu parçanın bu kısma kaynak yapılması ile bakır borunun (4) her iki ucu da kapatılmış ve vakum için uygun duruma getirilmiş olmaktadır. Böylece soğutma modülü tamamlanmış olmaktadır. 


\subsection{Soğutucu Modül Çalışma Şekli}

Aydınlatma armatürleri için yüksek 1sı atma kapasitesine sahip soğutucu modülünün çalışma şekli olarak; ilk önce LED ve PCB konumlandırma yeri olan bakır taban parçasına (5) kullanılan bakır boru (4) boyu ve kanatçık sayısı, kalınlı̆̆ı, yüzey alanı, birbirleri arasındaki mesafe sertliğine göre uygun güçte olan bir LED, PCB'si ile bağlanarak her ikisine de güç verilir. LED verilen gücün büyük bir kısmını 1sı enerjisine çevirerek oluşan 1s1 PCB'ye ve oradan da sirasiyla bakır taban parçasına (5), bakır boruya (4), alüminyum kanatçık boğazlarına (3), alüminyum kanatçıklara (2) geçerek son olarak da diş ortama atılmaktadır. Çalışma esnasında soğutucu modülde bulunan bakır borunun (4) içi akışkan sıvı ile doldurulduktan sonra bir vakum pompası ile akışkan sıvının ısınmanın etkisi ile gerçekleşecek buharlaşma-yoğuşma çevrimi daha hızlı olması amacıyla vakum oluşturulmuştur. LED'in ürettiği 1S1 enerjisi vakumlu ortamda 1sinarak buharlaştıktan sonra bakır borunun (4) üst kısımlarına doğru hareket eder. Hareket ederken 1sı enerjisini alüminyum kanatçık boğazlarından (3) alüminyum kanatçıklara (2) aktarır ve hızlıca 1 sı kaybeder. Yoğuşma noktasına gelen yoğuşan kısım bakır borunun (4) iç çeperlerinde gözenekli olan sinter parçası kısmına (6) gelerek gözenekler vasıtasıyla kılcal etki yaratılıp LED in bulunduğu taban parçası (5) kısmına gelerek tekrar enerji kazanıp buharlaşarak tekrar yukarı hareket edip bir buhar-yoğuşma çevrimi gerçekleştirmektedir.

\subsection{Tasarım Gereksinimleri ve Çözümler}

İmal edilmiş modülün kullanılmasıyla kapsamında mevcut LED soğutma modüllerinin belli başlı teknik sorunlarına çözüm getirilmiştir. Is1 transferini sağlayan faz değişimi birbirine temas eden katı yüzey ile sıvı arasındaki sıcaklık farkı kabul edilebilir düzeyde olduğunda meydana gelir [15]. Burada önemli olan nokta boru çapının taşıyabileceği akışkan sıvı miktarıdır. Borunun dış çeperlerine belli aralıklarla dizilen kanatçıklar, akışkan sıvının taşıdığı 1sı enerjisini aynı oranda alarak diş ortama atmaktadırlar. Bu homojen taşıma durumu tüm kanatçıkların maksimum performansta çalışmasını sağlayarak daha dar yüzeylerden daha çok 1sı enerjisi atılmasını sağlamaktadır. Ayrıca daha dar yüzeyler kullanıldığında normal olarak daha hafif bir soğutma modülü ortaya çıkmaktadır.

$\mathrm{Bu}$ modülün kullanılmasıyla elde edilen bir diğer önemli yenilikçi yön de kanatçıkların dizildiği borunun iç yüzeyinde bir kılcal boru etkisi oluşturarak buharlaşıp enerjisini kanatçıklara aktaran akışkanın yoğunlaştıktan sonra kılcal etki ile çok hızlı bir biçimde geri dönmesi ve dolayısıyla bu hızlı çevrim sayesinde hızlı bir 1sı transferi sağlanmaktadır. Bu durum borunun iç çeperlerine boru ile aynı malzemede olan metal tozunun yüksek sıcaklıkta yapıştırılması ve iç yüzeyde küçük delikli porozif ve geçirgen bir yapı oluşturularak kohezyon kuvveti meydana getirilmesini sağlamıştır. Kohezyon kuvveti etkisini artırmak için de boru iç yüzeyinde koniklik yaratılarak sıvı moleküllerinin konikliğin etkisi ile daha da hızlı çevrime girmesi gerçekleştirilmiştir.

$\mathrm{Bu}$ buluşun içerisinde gerçekleştirilen kanatçık dizme çalışmalarında da boruya dizilecek kanatçıkların kalınlıkları, yüzey alanları, boğaz mesafeleri, sık1 geçme toleransları, birbiri arasındaki aralık mesafeleri ve 1s1 enerjisi atma kapasitesine göre kullanılacak kanatçık sayısı belirlenmiş ve bu alanda optimizasyonlar yapılmıştır. Solidworks platformunda tasarlanan prototip ürünün görseli Şekil 1 ve Şekil 2'de verilmiştir.

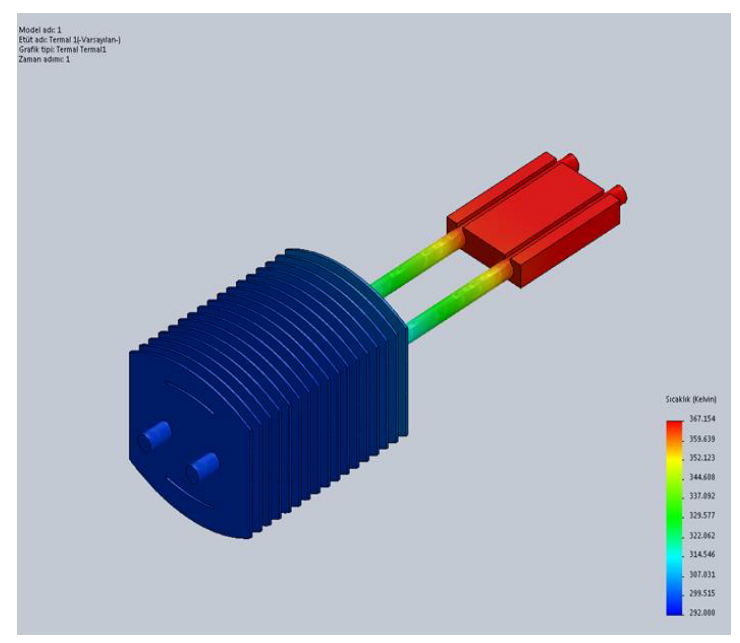

Şekil 2. Tasarlanan prototip ürün görüntüsü 
Geliştirilen soğutma modülünde kullanılan borunun her iki tarafı da kaynak ile mühürlenerek kapatılmış ve bu sayede borunun iç kısmında bir vakum yaratılarak akışkan sıvı çevriminin daha hızlı gerçekleşmesi sağlanmıştır. Her iki tarafa yapılan kaynak ile mühürleme sayesinde vakum durumunda herhangi bir olumsuz durum yaşanmamakta ve modül daha uzun zaman çevrim yapmaya devam edebilmektedir.

\section{BULGULAR VE TARTIŞMA}

\subsection{Performans Karşılaştırması}

İmal edilen soğutucu modülünün performansını ölçmek amacıyla Şekil 3’te gösterilen piyasadaki hazır soğutucu modülleri incelenmiştir. Farklı geometrik şekillerde olan 4 adet soğutucu modül üzerinde $9 \mathrm{~W} 450 \mathrm{~mA}$ XP-G LED kullanılarak bağlantı noktası ve gövde sıcaklıkları ölçülmüştür.

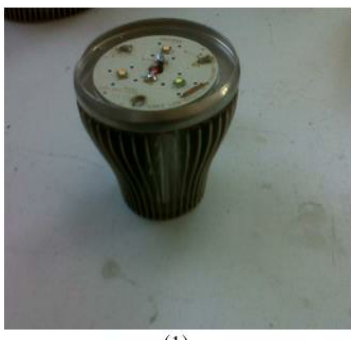

(1)

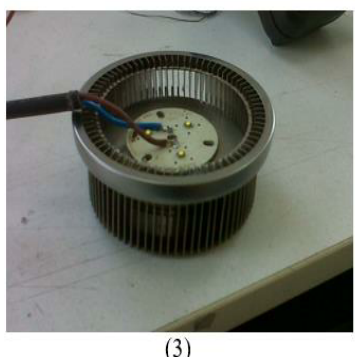

Şekil 3. Farklı geometrik şekillerde soğutucu modülleri

Aynı özelliklere sahip LED kullanılarak Şekil 4'te bu çalışmada imal edilen soğutucu modülünün bağlantı noktası ve gövde sıcaklık değeri de ölçülmüştür.

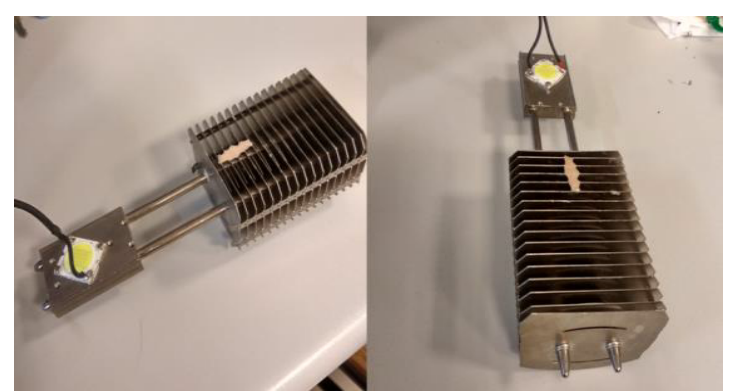

Şekil 4. Bu çalışmada imal edilen soğutucu modül

Sistemin enerjilendirilmesinden sonra ortalama $31{ }^{\circ} \mathrm{C}$ ortam sicaklığında 60 dakika boyunca yapılan sıcaklık ölçümleri Çizelge 1'de verilmiştir. Çizelge 1'de imal edilen soğutucu modülü bağlantı noktası ve gövde sıcaklık değerinin diğer modellere göre daha düşük olduğu görülmektedir. $\mathrm{Bu}$ ölçümler sonucunda LED isınma problemi için diğer modellere göre daha iyi soğutma sağlandığ 1 kanıtlanmıştır.

Çizelge 1. Soğutucu modüllerin sıcaklık değerleri

\begin{tabular}{|l|c|c|c|}
\hline & $\begin{array}{c}\text { Ortam } \\
\text { Sıcaklığı } \\
\left({ }^{\mathbf{0}} \mathbf{C}\right)\end{array}$ & $\begin{array}{c}\text { Bağlantı } \\
\text { noktası } \\
\text { Sıcaklığı } \\
\left.\mathbf{}^{\mathbf{0}} \mathbf{C}\right)\end{array}$ & $\begin{array}{c}\text { Gövde } \\
\text { Sicaklığı } \\
\left({ }^{\mathbf{}} \mathbf{C}\right)\end{array}$ \\
\hline Model 1 & 33 & 50 & 50 \\
\hline Model 2 & 31 & 57 & 48 \\
\hline Model 3 & 32 & 49 & 39 \\
\hline Model 4 & 31 & 55 & 39 \\
\hline $\begin{array}{l}\text { İmal } \\
\text { edilen } \\
\text { model }\end{array}$ & 31 & 43 & 36 \\
\hline
\end{tabular}

\subsection{Sıcaklık Testi Çalışmaları}

Üretilen prototipin termal kamera ile test edilmesi sırasında dışardan gelen 1şıkların sıcaklık testlerinde doğru sonuçları vermeleri için karanlık test ünitesi oluşturulmuş ve Şekil 5 'te görüldüğü gibi testlere tabi tutulmuştur. Bu bölümde $9 \mathrm{~W}$ Power LED daha yüksek güçte çalıştırılarak soğutucu modülün sportif ve otoyol aydınlatmalarında kullanımına uygun olup olmadığı incelenmiştir. 


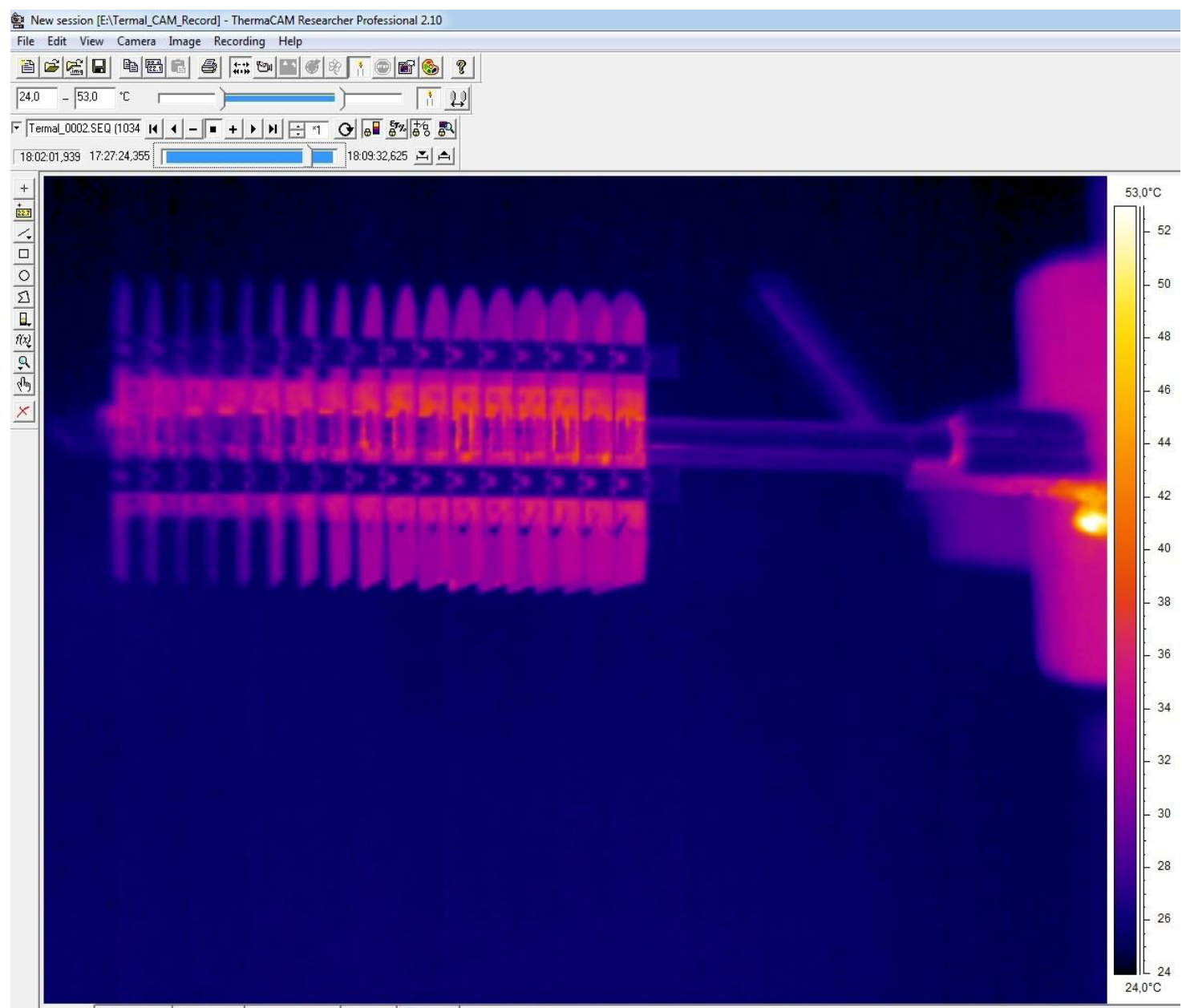

Şekil 5. Soğutucu modül termal kamera görüntüsü

Proje kapsamında alınan termal kamera ve Jumo test cihazı kullanılarak sicaklıklar incelenmiştir (Şekil 6).

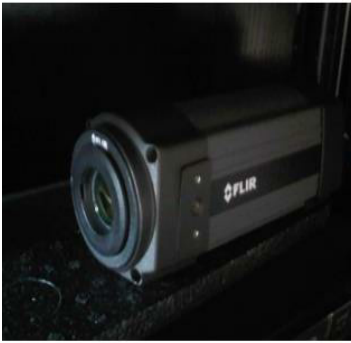

(a)

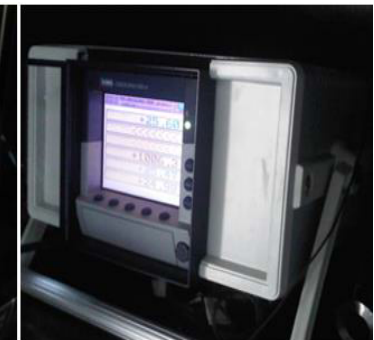

(b)
Şekil 6. Termal kamera (a) ve Jumo (b) cihazları
Oluşturulan mekanik soğutucu üzerine 9 W'lık Power LED bağlanarak, sıcaklık değişimleri incelenmiştir. $\mathrm{Bu}$ incelemeler proje kapsamında alınan Jumo cihazı ve Termal Kamera ile ölçülerek kıyaslanmıştır. Jumo'ya 5 adet termokupl bağlanarak 5 farklı noktadan ölçümleri yapılmıştır. Dakika başına alınan değerler bilgisayar ortamına aktarılarak sıcaklık değişimleri incelenmiş ve her ayrı model ve LED özelliklerine göre sıcaklık zaman değişim grafikleri oluşturulmuştur. Termal kamera analizleri ve sonuçlarından oluşturulan test 1 ve test 2'nin sonuçları Çizelge 2'de verilmiştir. Test 2'de hesaplanan güçteki 4,5 W'lık artış ile birlikte LED'in bağlantı noktası sıcaklığının $16{ }^{\circ} \mathrm{C}$ kadar arttığı görülmektedir. 
Çizelge 2. Test 1 ve test 2 ölçüm değerleri

\begin{tabular}{|c|c|c|}
\hline & Test 1 & Test 2 \\
\hline Ölçülen Voltaj (V) & 6,4 & 7,4 \\
\hline Ölçülen Akım (A) & 1,7 & 2,1 \\
\hline Hesaplanan Güç (W) & 11 & 15,5 \\
\hline $\mathrm{Ts} *\left({ }^{\circ} \mathrm{C}\right)$ & 22 & 22 \\
\hline $\mathrm{Ta}^{*}\left({ }^{\circ} \mathrm{C}\right)$ & 38 & 47 \\
\hline $\mathrm{Tj}^{*}\left({ }^{\circ} \mathrm{C}\right)$ & 54 & 70 \\
\hline Test Süresi (saat) & 1 & 1,5 \\
\hline \multicolumn{3}{|c|}{$\begin{array}{l}\text { *Ts: Ortam sıcaklığı } \\
\text { * Ta: PCB montaj yüzey sıcaklığı } \\
\text { * Tj: LED - Çip bağlantı noktası sıcaklığ } 1\end{array}$} \\
\hline
\end{tabular}

Oluşturulan prototiplerin termal kamera ile sıcaklık değişimleri incelenmiştir. Sistem stabil hale geldiğinde boru üzerindeki ve bir alüminyum kapakçık üzerindeki sıcaklık değişimleri grafikleri oluşturulmuş ve sıcaklık farkları incelenmiştir. Şekil 7'de test 1 ve Şekil 8'de test 2'de ölçülen sicaklık değerinin grafikleri verilmiştir. Şekil 8'deki grafiğe göre ortalama PCB montaj yüzey sıcaklığı $38{ }^{\circ} \mathrm{C}$, ortam sicaklığ $22{ }^{\circ} \mathrm{C}$ ve bağlantı noktası sıcaklığı $54{ }^{\circ} \mathrm{C}$ 'dir.

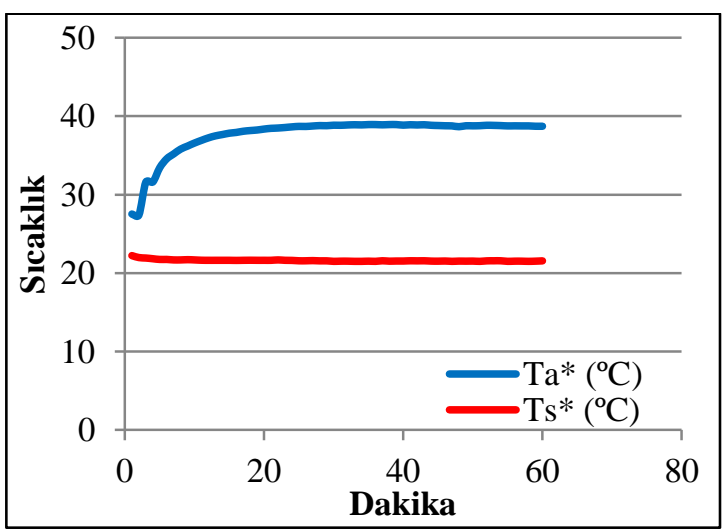

Şekil 7. Test 1 sıcaklık grafiği

Şekil 8' deki grafiğe göre ise ortalama PCB montaj yüzey sicaklığı $47{ }^{\circ} \mathrm{C}$, ortam sicaklığ $22{ }^{\circ} \mathrm{C}$ ve bağlantı noktası sıcaklığı $70{ }^{\circ} \mathrm{C}$ 'dir. Kullanılan Power LED'in çalışması için maksimum bağlantı sicaklığ $90{ }^{\circ} \mathrm{C}$ 'dir. Her iki test sonucunda $22{ }^{\circ} \mathrm{C}$ ortam sıcaklığında kullanılan Power LED için yeterli soğutmayı sağladığı görülmektedir.

\section{SONUÇ VE ÖNERILLER}

$\mathrm{Bu}$ çalışmada soğutucu modül tasarımı geliştirilmiş ve imal edilmiştir. İmal edilen prototip üzerinde sicaklık testleri yapılmış ve piyasadaki diğer soğutucu modüllerle karşılaştırması yapılarak performansı incelenmiştir. Sportif aydınlatmada ve otoyol aydınlatmalarında büyük ölçüde kullanılabilir olduğu görülmüştür.

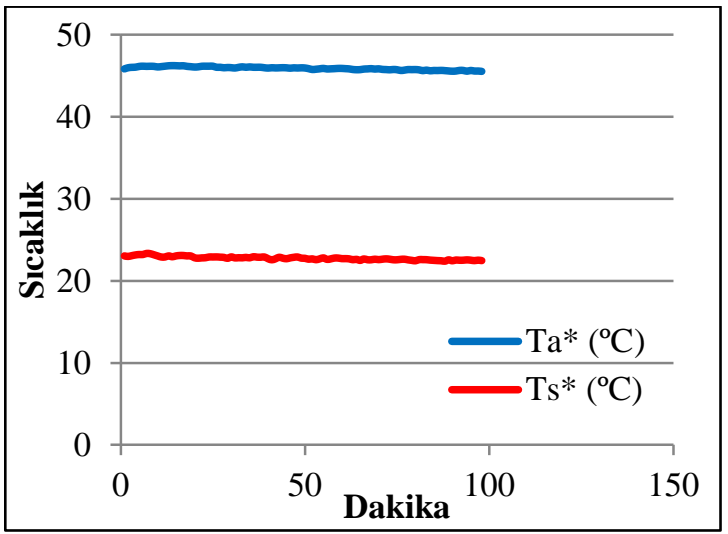

Şekil 8. Test 2 sıcaklık grafiği

Geliştirilen soğutucu modül birçok yeniliğe ve avantaja sahiptir. Bu yeniliklerden biri geliştirilen buluş ile yüksek güce sahip LED'lerin büyük hacimli ve ağır kütleler kullanılmadan soğutulmasının gerçekleştirilmesidir. Kullanılan teknik ile 1sı transferi daha hızlı yapılmakta ve bunun için büyük yüzeylere gerek duyulmadan çok daha küçük yüzeylerden büyük kapasitede 1s1 dışarıya atılmaktadır.

Geliştirilen soğutma modülünde 1sı atma yüzeyleri ince bir alüminyum levha olarak üst üste dizildiğinden ve aynı zamanda ısı transferinin homojen ve çok hızlı bir şekilde yapılmasından dolayı büyük yüzey alanlarına sahip ağır alüminyum bloklar kullanılmasına gerek duyulmamaktadır.

Oluşturulan PCB-LED ve soğutucu yan yana getirilerek veya ayrı ayrı kullanılarak modüler bir yap1 oluşturulabilmektedir. Geliştirilen modülde tek ve yüksek güç kapasitesine sahip LED'ler kullanılarak istenilen yerlere istenilen miktarda 
PCB-LED ve soğutucudan oluşan modülleri yerleştirmek ve istenildiğinde yerlerini değiştirmek mümkün olmaktadır.

Modüler yapıya sahip LED-PCB ve soğutucudan oluşan modül her açıda çalışabilir olacaktır. Bu nedenle 1 şık açısı ve gerekli yerlerde istenen aydınlatma şiddeti ayarlanabilir olmaktadır. Bu durum armatürlerde kullanılan lens ve reflektör tasarımına son derece fayda sağlayarak daha iyi bir aydınlatma ortamı oluşturulmasına katkıda bulunmaktadır.

\section{KAYNAKLAR}

1. Lenk, R., Lenk, C., 2016. Practical Lighting Design with LEDs, Wiley-IEEE Press, 1, 304-307.

2. Çelik, K., Ünver, F.R., 2019. Eğitim Yapılarında Sürdürülebilir Aydınlatma Tasarımı Yaklaşımı. Çukurova Üniversitesi Mühendislik Mimarlık Fakültesi Dergisi, 34(3), 49-63.

3. Badalan, N., Svasta, P., 2017. Fan vs. Passive Heat Sink with Heat Pipe in Cooling of HighPower LED, 2017 IEEE 23 ${ }^{\text {rd }}$ International Symposium for Design and Technology in Electronic Packaging (SIITME), Constanta, 296-299.

4. Jang, D., Yook, S.J., Lee, K.S., 2014. Optimum Design of a Radial Heat Sink with a Fin-Height Profile for High-Power LED Lighting Applications. Applied Energy, 116, 260-268.

5. Jang, D., Yu, S.H., Lee K.S., 2012. Multidisciplinary Optimization of a Pin-Fin Radial Heat Sink for LED Lighting Applications, International Journal of Heat Mass Transfer, 55(4), 515-521.

6. Amini, M., Jani, S., Mahmoodi, M., Jam, J.M., 2014. Numerical Investigation of Natural Convection Heat Transfer in a Symmetrically Cooled Square Cavity with a Thin Fin on its Bottom Wall, Thermal Science, 18, 1119-1132.

7. Huang, Y., Shen, S., Li, H., Gu, Y., 2019. Numerical Analysis on the Thermal Performances of Different Types of Fin Heat
Sink for High-Power Led Lamp Cooling, Thermal Science, 23(2), 625-636.

8. Huang, Y., Shen, S., Li, H., Gu, Y., 2016. Improved Thermal Design of Fin Heat Sink for High-Power LED Lamp Cooling, 2016 $17^{\text {th }}$ International Conference on Electronic Packaging Technology (ICEPT), 1069-1074.

9. Karatekin, C., Kökkaya, O., 2018. Comparative Analysis of Different Cooling Fin Types for Countering LED Luminaires' Heat Problems, Turkish Journal of Electrical Engineering \& Computer Sciences, 26, 454-466.

10. Laad, P., Akhare, B., Chaurasia, P., 2016. Thermal Analysis of Heat Sink with Fins of Different Configuration Using Ansys Workbench 14.0, International Journal of Engineering Sciences and Research Technology, 5(6), 82-93.

11. Zheng, J., Ge, D., Li, J., 2015. The Analysis of Heat Pipe Cooling in High Power LED Lighting System, $201516^{\text {th }}$ International Conference on Electronic Packaging Technology (ICEPT), Changsha, 480-482.

12. Xiao, C., Liao, H., Wang, Y., Li, J., Zhu, W., 2017. A Novel Automated Heat-Pipe Cooling Device for High-Power LEDs, Applied Thermal Engineering, 111, 1320-1329.

13. Zheng, H., Xu, C., Liu, J., Chu, J., Liu, S., Zeng, X., Sun, R., 2017. A Novel Cooling Method for LED Filament Bulb Using Ionic Wind, 2017 16th IEEE Intersociety Conference on Thermal and Thermomechanical Phenomena in Electronic Systems (ITherm), Orlando, FL, 998-1003.

14. Çiçek, B., Şahin, N., 2020. Sokak Aydınlatmalarında Kullanılacak Yüksek Güçlü LED'lerin Termal Performansının Sayısal ve Deneysel Olarak İncelenmesi, Journal of Engineering Sciences and Design, 8(1), 185-197.

15. Karaçaylı, İ., Şimşek, E., Altay, L., Hepbaşl1, A., 2018. Experimental and Analytical Investigation of Heat Transfer Coefficient of a Water-Cooled Condenser for Different Water Flows and Condensation Pressures, Çukurova Üniversitesi Mühendislik Mimarlık Fakültesi Dergisi, 33(2), 101-112. 